\title{
Precocious puberty in girls: early diagnosis of a slowly progressing variant
}

\author{
M FONTOURA, R BRAUNER, C PREVOT, AND R RAPPAPORT \\ Paediatric Endocrinology Unit and INSERM U30, Hôpital des Enfants Malades, Paris, France
}

SUMmaRY An attempt was made to identify the less severe cases of precocious puberty and to describe their natural course. A group of 17 girls with precocious puberty and a bone age advance over chronological age of less than two years (group 1) was compared with a group of 19 patients with severe precocious puberty and bone age advance of two years or more (group 2). Mean (SEM) plasma oestradiol concentrations were $82(30) \mathrm{pmol} / 1$ and $164(21) \mathrm{pmol} / \mathrm{l}(\mathrm{p}<0 \cdot 05)$, vaginal maturation indexes were $16(5)$ and $41(4)$, and plasma somatomedin $C$ concentrations were $1 \cdot 0(0 \cdot 2) \mathrm{U} / \mathrm{ml}(\mathrm{n}=8)$ and $2 \cdot 1(0 \cdot 3) \mathrm{U} / \mathrm{ml}(\mathrm{n}=16)$ in groups 1 and 2 , respectively. The time between onset and diagnosis of secondary sexual characteristics was about one year in both groups. After two years' follow up the untreated patients in group 1 had maintained their predicted final height. These changes were in contrast to those observed at first examination in patients in group 2 who had a mean (SD) predicted final height of $-1 \cdot 3(0 \cdot 2)$ and a mean bone age advance of $3 \cdot 0(0 \cdot 2)$ years. These data show that bone age advance to chronological age, and plasma somatomedin $C$ concentrations measured at initial evaluation are helpful in identifying less severe and potentially slow progressing forms of central precocious puberty.

Children with central precocious puberty have a premature increase in the secretion of sex hormones that leads to acceleration of their growth rate. At the same time excessive progression of bone age may lead to short adult stature. The course of sexual precocity is variable, however, and in some cases normal growth continues with no reduction in predicted final height. ${ }^{1}$ This clinical heterogeneity may partly explain the difficulty that has been encountered in establishing the effectiveness of treatment with cyproterone acetate ${ }^{2}$ or medroxyprogesterone. ${ }^{3}$ More recently drugs such as luteinising hormone releasing hormone analogues have been shown to suppress gonadotrophin secretion and gonadal activity completely. Data from short term trials have already shown that there is an increase in the predicted final height. ${ }^{48}$ We have studied the spontaneous course of precocious puberty according to its initial presentation, to evaluate the early use of luteinising hormone releasing hormone analogues.

\section{Patients and methods}

Thirty six girls with idiopathic precocious puberty who had been regularly followed up in the paediatric endocrinology unit were assigned to this study. Informed consent was obtained from both them and their parents. The diagnostic criterion of precocious puberty was the occurrence of oestrogenic activity in association with the appearance of pubic hair before age of 8 years. Primary ovarian follicular cysts and adrenal diseases were ruled out. The plasma concentrations of $\beta$ human chorionic gonadotrophin and $\alpha$ fetoprotein were normal. A computed tomogram of the head was carried out in all cases and was normal. No patient had previously received treatment for precocious puberty. Growth hormone secretion, evaluated by the arginine-insulin tolerance test, was normal.

Patients were arbitrarily classified into two groups (table 1) according to their bone age advance over chronological age at first examination: group $1 \mathrm{com}-$ prised patients in whom the advance was less than two years (cases 1-17) and group 2, patients in whom it was more than two years (cases 18-36). The bone age advance was selected as a discriminatory criterion because it had been used in this group to decide which patients were to receive treatment with the luteinising hormone releasing hormone 
Precocious puberty in girls: early diagnosis of a slowly progressing variant

Table 1 Clinical and biological data for 36 girls with precocious puberty at time of first examination

\begin{tabular}{|c|c|c|c|c|c|c|c|c|c|}
\hline $\begin{array}{l}\text { Case } \\
\text { No }\end{array}$ & $\begin{array}{l}\text { Chronologica } \\
\text { age } \\
\text { (years) }\end{array}$ & $\begin{array}{l}\text { l Bone } \\
\text { age } \\
\text { (years) }\end{array}$ & $\begin{array}{l}\text { Height } \\
(S D)\end{array}$ & $\begin{array}{l}\text { Pubertal } \\
\text { stage }^{y}\end{array}$ & $\begin{array}{l}\text { Plasma } \\
\text { oestradiol } \\
\text { concentration } \\
\text { (pmol/l) }\end{array}$ & $\begin{array}{l}\text { Vaginal } \\
\text { maturation } \\
\text { index }\end{array}$ & $\begin{array}{l}\text { Peak plasma } \\
\text { luteinising } \\
\text { hormone } \\
\text { concentration } \\
(I U / l)\end{array}$ & $\begin{array}{l}\text { Peak follicle } \\
\text { stimulating } \\
\text { hormone } \\
\text { concentration } \\
\text { (IU/l) }\end{array}$ & $\begin{array}{l}\text { Plasma } \\
\text { somatomedin C/ } \\
\text { insulin like } \\
\text { growth factor } I \\
\text { concentration } \\
(\text { U/ml })\end{array}$ \\
\hline
\end{tabular}

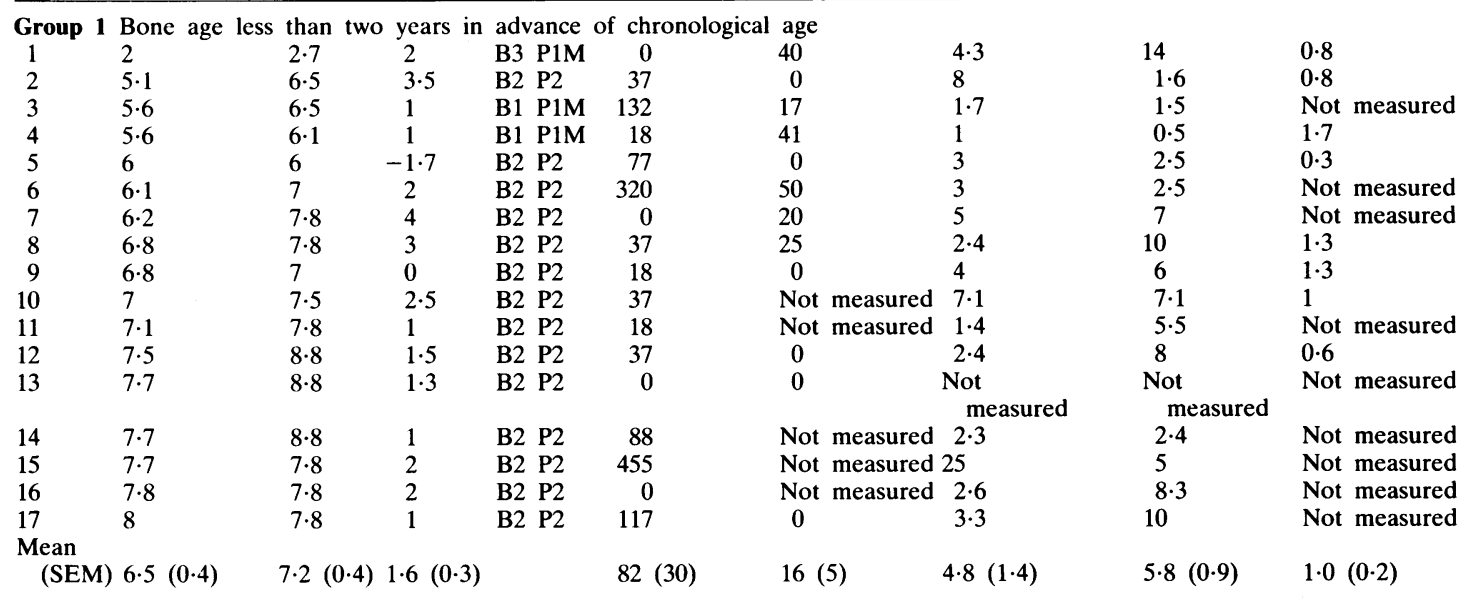

\begin{tabular}{|c|c|c|c|c|c|c|c|c|c|}
\hline Group 2 & Bone age & more than th & wo years i & advance & of chron & age & & & \\
\hline 18 & $3 \cdot 4$ & $5 \cdot 5$ & 3 & B2 P3M & 183 & 50 & 28 & 14 & $1 \cdot 3$ \\
\hline 19 & $3 \cdot 5$ & 6 & 3 & B3 P2 & 132 & 45 & - & - & 1.9 \\
\hline 20 & $4 \cdot 6$ & $10 \cdot 5$ & $4 \cdot 5$ & B2 P2 & 55 & 40 & 35 & 20 & $1 \cdot 7$ \\
\hline 21 & $6 \cdot 2$ & 9 & $2 \cdot 0$ & B3 P2 & 183 & 55 & 10 & 10 & $4 \cdot 7$ \\
\hline 22 & $6 \cdot 6$ & $10 \cdot 5$ & $3 \cdot 5$ & B4 P2 & 37 & 42 & 30 & $12 \cdot 5$ & $2 \cdot 3$ \\
\hline 23 & $7 \cdot 2$ & $10 \cdot 5$ & 2 & B3 P4 & 110 & 49 & 8 & 9 & - \\
\hline 24 & $7 \cdot 7$ & 10 & 1 & B2 P4 & 147 & 3 & 3 & $7 \cdot 3$ & $1 \cdot 3$ \\
\hline 25 & $7 \cdot 7$ & $10 \cdot 5$ & $1 \cdot 5$ & B3 P3 & 257 & 50 & 10 & 7 & 3 \\
\hline 26 & $7 \cdot 7$ & 11 & 1.5 & B3 P3 & 73 & 21 & 12 & 11 & - \\
\hline 27 & $7 \cdot 8$ & $10 \cdot 5$ & 2 & B2 P2 & 73 & 45 & 11 & 13 & 1.2 \\
\hline 28 & 8 & $10 \cdot 5$ & 3 & B3 P3 & 128 & 0 & $8 \cdot 5$ & 1 & 0.8 \\
\hline 29 & $8 \cdot 2$ & 11 & $3 \cdot 0$ & B3 P3 & 202 & 43 & 10 & $6 \cdot 5$ & $1 \cdot 2$ \\
\hline 30 & $8 \cdot 3$ & 11 & $2 \cdot 5$ & B4 P4 & 271 & 40 & 3 & $6 \cdot 3$ & $2 \cdot 7$ \\
\hline 31 & 8.4 & 12 & $2 \cdot 5$ & B3 P2M & 238 & 58 & 66 & 12 & 1.9 \\
\hline 32 & $8 \cdot 8$ & 12 & $-0 \cdot 5$ & B2 P2 & 220 & 52 & 10 & $9 \cdot 3$ & 2.9 \\
\hline 33 & $8 \cdot 8$ & 11 & 2 & B3 P3 & 110 & 40 & 8 & $7 \cdot 6$ & 0.9 \\
\hline 34 & $8 \cdot 8$ & 12 & $3 \cdot 5$ & B3 P2M & 183 & 52 & 11 & 5 & $3 \cdot 3$ \\
\hline 35 & $8 \cdot 8$ & 11 & $2 \cdot 5$ & B3 P3 & 110 & 47 & 16 & 7 & $2 \cdot 5$ \\
\hline 36 & 8.9 & $12 \cdot 5$ & 2 & B4 P5M & 404 & 50 & 44 & 31 & - \\
\hline Mean & & & & & & & & & \\
\hline (SEM) & $7 \cdot 3(0 \cdot 4)$ & $10.4(0.4)$ & b) $2.4(0.2$ & & $164(21)$ & $41(4)$ & $18(4)$ & $10 \cdot 5(1.5)$ & $2 \cdot 1(0.3)$ \\
\hline $\begin{array}{l}\text { p Value } \\
\text { compared } \\
\text { with } \\
\text { group } 1\end{array}$ & $\begin{array}{l}\text { d } \\
<0.2\end{array}$ & $<0.001$ & $<0.1$ & & $<0.05$ & $<0.01$ & $<0.01$ & $<0.01$ & $<0.01$ \\
\hline
\end{tabular}

analogue. In group 1 the spontaneous course of precocious puberty was followed up for a period of two years after the first examination and the patients received no treatment, with the consent of their parents. The patients in group 2 were treated with the analogue (Buserelin) after the first examination.
The mean (SEM) chronological ages in the two groups at the time of first examination was $6.5(0.4)$ years (range 2-8) and $7 \cdot 3(0.4)$ years (range $3 \cdot 4-8 \cdot 9$ ), respectively.

The mean (SEM) time intervals between the onset of sexual development and the first examina- 
tion were similar in both groups, being $0.7(0.2)$ years (range 0.2-1) and 1.0 (0.2) (range 0.3-1.1), respectively.

Puberty ratings were made according to Tanner's scale. ${ }^{9}$ Height changes were expressed as standard deviation scores taking the chronological age or the bone age as the reference measurement. Final heights were predicted according to the method Bayley and Pinneau ${ }^{10}$ using the bone age as assessed by Greulich and Pyle. ${ }^{11}$ Final predicted heights were expressed in relation to the mean normal adult height using standard deviation scores. ${ }^{12}$

All patients were evaluated according to previously published methods for growth hormone secretion (arginine-insulin tolerance test ${ }^{13}$ ) and basal serum values of oestradiol and somatomedin C/insulin like growth factor $\mathrm{I}^{14}$ The gonadal hypothalamic-pituitary axis was investigated by basal and luteinising hormone releasing hormone stimulated measurements of plasma luteinising hormone, and follicle stimulating hormone, as previously reported. ${ }^{15}$ The vaginal maturation index was evaluated by vaginal smear examination with an upper normal prepubertal value of $35 .^{16}$

The vaginal maturation index was not evaluated in cases $10,11,14,15$, and 16 at the time of their first examination. Cases 13 and 19 were not tested for luteinising hormone releasing hormone at their initial examination. All data are expressed as mean (SEM) and statistical comparisons were made by
Student's paired $t$ test on the same group, and by the unpaired $t$ test between groups 1 and 2 .

\section{Results}

COMPARISON AT TIME OF DIAGNOSIS BETWEEN THE TWO GROUPS OF PATIENTS

Tables 1 and 2 show the clinical presentation and biological data of the two groups. The distribution of the breast development stage in relation to the bone age advance is shown in the figure. The mean chronological ages at the first evaluation and the mean time from the onset of sexual development were similar in both groups. By definition the mean bone age advance (expressed as bone age minus chronological age) was significantly lower in patients in group $1(0.7(0.1)$ years) compared with group 2 $(3(0.2)$ years $)(p<0.001)$. The mean height gains during the year before the initial evaluation were similar in both groups, $7 \cdot 8(0.8) \mathrm{cm}$ and $8.5(0.4) \mathrm{cm}$, respectively. Patients of group 1 were, however, slightly but not significantly shorter, with a mean (SD) height score for chronological age of 1.6 $(0 \cdot 3)$ above the normal mean compared with $2.4(0.2)$ for patients of group $2(\mathrm{p}<0.05)$.

Patients in group 1 also had fewer clinical signs of excessive oestrogen production when first seen: vaginal bleeding in two cases (cases 3 and 4), breast development at Tanner's stage 2 in 14 patients, and stage 3 in one case (table 1). Pubic hair was present

Table 2 Spontaneous growth and bone maturation during the two years following the first examination in girls with precocious puberty and moderate oestrogen activity (group 1)

\begin{tabular}{|c|c|c|c|c|c|c|}
\hline \multirow[t]{2}{*}{$\begin{array}{l}\text { Case } \\
\text { No }\end{array}$} & \multicolumn{2}{|c|}{$\begin{array}{l}\text { Bone age - chronological } \\
\text { age (years) }\end{array}$} & \multicolumn{2}{|c|}{ Height (SD) } & \multicolumn{2}{|c|}{$\begin{array}{l}\text { Height prediction } \\
\text { (standard deviation score) }\end{array}$} \\
\hline & 0 & After 2 years & 0 & After 2 years & 0 & After 2 years \\
\hline 1 & 0.7 & 0.9 & $2 \cdot 0$ & $2 \cdot 0$ & Not known & Not known \\
\hline 2 & $1 \cdot 4$ & 0.9 & $3 \cdot 5$ & 3 & Not known & 1 \\
\hline 3 & 0.9 & 0.9 & $1 \cdot 0$ & 2 & Not known & $0 \cdot 8$ \\
\hline 5 & 0 & $1 \cdot 6$ & -1.7 & $-0 \cdot 3$ & Not known & $-2 \cdot 2$ \\
\hline 6 & 0.9 & $1 \cdot 2$ & $2 \cdot 0$ & $1 \cdot 6$ & $0 \cdot 1$ & 0 \\
\hline 7 & $1 \cdot 6$ & 0.5 & $4 \cdot 0$ & 3 & $1 \cdot 2$ & $1 \cdot 5$ \\
\hline 8 & $1 \cdot 0$ & 0.8 & $3 \cdot 0$ & 3 & $-0 \cdot 1$ & $1 \cdot 4$ \\
\hline 9 & $0 \cdot 2$ & 0.9 & 0.0 & -0.5 & $-1 \cdot 1$ & -0.9 \\
\hline 10 & 0.5 & 0.9 & $2 \cdot 5$ & $2 \cdot 5$ & $1 \cdot 8$ & $1 \cdot 1$ \\
\hline 11 & 0.7 & $1 \cdot 5$ & $1 \cdot 0$ & 1 & 0.5 & -0.3 \\
\hline 12 & $1 \cdot 3$ & $1 \cdot 1$ & $1 \cdot 5$ & 0.7 & 0 & $-1 \cdot 2$ \\
\hline 14 & $1 \cdot 1$ & $1 \cdot 2$ & $1 \cdot 0$ & 0 & $0 \cdot 2$ & Not known \\
\hline 15 & $0 \cdot 1$ & $1 \cdot 8$ & $2 \cdot 0$ & 3 & $1 \cdot 2$ & -0.1 \\
\hline 16 & 0 & $1 \cdot 5$ & $2 \cdot 0$ & 2 & $1 \cdot 5$ & 1 \\
\hline 17 & $-0 \cdot 2$ & $1 \cdot 1$ & $1 \cdot 0$ & $0 \cdot 8$ & $0 \cdot 5$ & $-0 \cdot 1$ \\
\hline Mean (SEM) & $0.7(0 \cdot 1)$ & $1 \cdot 1(0 \cdot 1)^{*}$ & $1.6(0.3)$ & $1.6(0.4)$ & $0.4(0.2)$ & $0.1(0.3)$ \\
\hline
\end{tabular}

${ }^{*} \mathrm{p}<0.05$ compared with value at time 0 . 


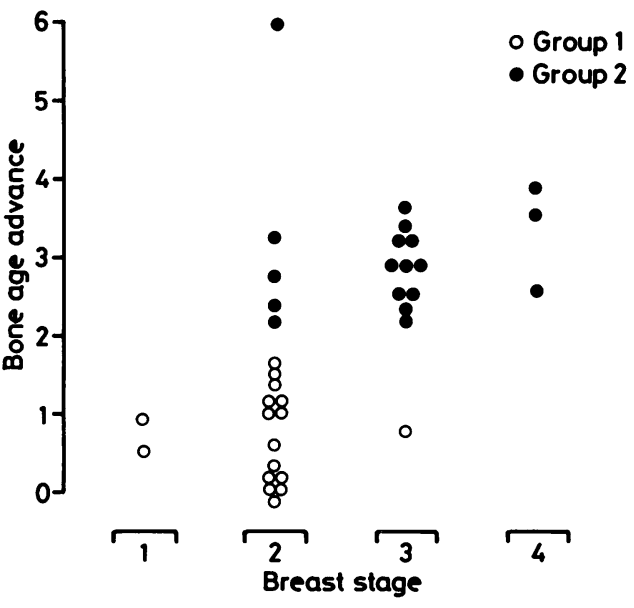

Figure Distribution of the breast development stage in relation to bone age advance (bone age-chronological age) in girls with precocious puberty.

at first examination in 14 patients (stage 2), and the remaining three patients (cases 1,3 , and 4 ) developed pubic hair within eight months of diagnosis. All patients had pubic hair before the age of 8 years. Patients 7, 9, 11, and 16 had recurrent and spontaneously reversible spurts of breast development.

The initial biological data are shown in table 1. In group 1 , the mean concentration of circulating oestradiol was $82(30) \mathrm{pmol} / \mathrm{l}$ (range 0-455). All except cases 6 and 15 had concentrations of less than $132 \mathrm{pmol} / \mathrm{l}$. The mean vaginal maturation index was 16 (5) (range 0-50), mean luteinising hormone peak was $4.8(1.4) \mathrm{IU} / \mathrm{l}$ (range 1-25), and the mean follicle stimulating hormone peak was $5.8(0.9) \mathrm{IU} / \mathrm{l}$ (range 0.5-14). Eleven of 17 girls had no biochemical or cytological signs of oestrogen impregnation (oestradiol concentration $<92 \mathrm{pmol} / \mathrm{l}$ and vaginal maturation index $<35$ ). In spite of the persistence of breast development, the two patients with the highest initial plasma oestradiol concentra- tions (cases 6 and 15) had prepubertal oestradiol concentrations and vaginal maturation indexes when re-evaluated six months later. Pelvic ultrasound examination did not disclose any ovarian cysts.

In contrast, most patients in group 2, whose bone age advance was at least two years, had overt clinical and biological signs of excessive oestrogen production when first seen. Their breast development was equal or above stage 3 in 14 cases. In the remaining four cases it was stage 2 . In this group, the mean plasma concentration of oestradiol was 164 (21) $\mathrm{pmol} / \mathrm{l}$ (range 37-404), the mean vaginal maturation index was 41 (4) (range 0-58), the mean peak luteinising hormone was 18 (4) IU/l (range 3-66), and the mean peak follicle stimulating hormone was $10 \cdot 5(1.5) \mathrm{IU} / 1$ (range 1-31). All the values in group 2 were significantly greater than the mean values in group 1 (table 1). They were thought to reflect a more mature hypothalamic gonadotrophin axis.

Plasma somatomedin C concentrations were measured in only eight patients from group 1 and 16 patients from group 2 (table 3 ). The mean plasma somatomedin C concentration of $1.0(0.2) \mathrm{U} / \mathrm{ml}$ (range $0 \cdot 3-1.7$ ) in group 1 was significantly lower than that of $2 \cdot 1(0 \cdot 3) \mathrm{U} / \mathrm{ml}$ (range $0 \cdot 8-4 \cdot 7)$ in group $2(p<0.01)$. These two groups of patients also differed significantly in their plasma oestradiol concentrations (33 (11) pmol/l in group 1 and 154 (18) $\mathrm{pmol} / \mathrm{l}$ in group $2, \mathrm{p}<0.001)$. The growth rate was similar in the two groups, however, $(7 \cdot 8(0 \cdot 8)$ and $8.9(0.4) \mathrm{cm}$ in groups 1 and 2 , respectively). We found no correlation between plasma oestradiol concentration and growth rate or plasma somatomedin $\mathrm{C}$ concentrations, either within the groups or in the whole population.

\section{GROWTH IN UNTREATED PATIENTS WITH CENTRAL} PRECOCIOUS PUBERTY AND LOW OESTROGEN ACTIVITY

The spontaneous growth and bone maturation in patients in group 1 were analysed after a two year follow up period to evaluate the effect of persistently low oestrogenic activity (table 2). After two

Table 3 Plasma somatomedin C/insulin like growth factor I concentrations and growth in girls with mild (group 1) or severe (group 2) precocious puberty at time of first examination. Values are expressed as mean (SEM)

\begin{tabular}{|c|c|c|c|c|c|c|c|}
\hline Group & $\begin{array}{l}\text { No of } \\
\text { subjects }\end{array}$ & $\begin{array}{l}\text { Chronological } \\
\text { age (years) }\end{array}$ & $\begin{array}{l}\text { Bone age } \\
\text { (years) }\end{array}$ & $\begin{array}{l}\text { Bone age- } \\
\text { chronological } \\
\text { age (years) }\end{array}$ & $\begin{array}{l}\text { Plasma } \\
\text { somatomedin Cl } \\
\text { insulin like growth } \\
\text { factor I concentration } \\
(\mathrm{U} / \mathrm{ml})\end{array}$ & $\begin{array}{l}\text { Plasma } \\
\text { oestradiol } \\
\text { concentration } \\
(\text { pmol/l) }\end{array}$ & $\begin{array}{l}\text { Height } \\
\text { gain } \\
\text { (cm/year) }\end{array}$ \\
\hline $\begin{array}{l}1 \\
2 \\
\text { p Value }\end{array}$ & $\begin{array}{r}8 \\
16\end{array}$ & $\begin{array}{l}6 \cdot 0(0 \cdot 6) \\
7 \cdot 2(0 \cdot 5) \\
<0 \cdot 1\end{array}$ & $\begin{array}{l}6 \cdot 6(0 \cdot 7) \\
10 \cdot 2(0.5) \\
<0 \cdot 001\end{array}$ & $\begin{array}{l}0.7(0 \cdot 2) \\
3.0(0 \cdot 3) \\
<0.001\end{array}$ & $\begin{array}{l}1.0(0 \cdot 2) \\
2 \cdot 1(0.3) \\
<0.01\end{array}$ & $\begin{array}{l}9(3) \\
42(5) \\
<0 \cdot 001\end{array}$ & $\begin{array}{l}7.8(0.8) \\
8.9(0.4) \\
<0.3\end{array}$ \\
\hline
\end{tabular}


years the mean advance of bone age over chronological age was $1 \cdot 1(0 \cdot 1)$ years (range $0 \cdot 5-1 \cdot 8)$. This was slightly but significantly higher than the value of $0.7(0 \cdot 1)$ years found at the time of diagnosis $(p<0.05)$. The bone age advance had progressed by more than one year in only four of 17 children (cases $4,5,15$, and 16). It had remained unchanged or decreased in six cases and progressed slightly in the seven others. Height for chronological age, expressed by the standard deviation score, had a mean (SD) value of $1.6(0.4)$ compared with a similar initial value of $1.6(0 \cdot 3)$. The mean (SD) final height prediction in these patients remained unchanged $(0.1(0 \cdot 3))$ from the initial value in the group of 12 patients evaluated at the time of diagnosis $(0.4$ (2.2)). Interestingly, among the four patients with the greatest progression of bone maturation, only one (case 5) had a low final height at $2 \cdot 2$ standard deviations below the normal mean.

The results for the patients in group 1 were also compared with the initial data for patients in group 2 at the time of diagnosis when precocious puberty had already accelerated bone maturation by more than two years. The mean (SD) predicted final height of patients in group 2 was $-1.3(0.2)$ below the normal mean, a value significantly lower than that calculated for patients in group $1(0 \cdot 1(0 \cdot 3))$ after a much longer period of spontaneous progression of the disease $(p<0.01)$. This comparison indicates that, despite nearly three years exposure to low or variable oestrogen activity in group 1, growth had remained sufficient in relation to bone maturation to permit a satisfactory mean final height prediction. This had not been the case in patients in group 2 seen after an average period of only one year who presented with pronounced oestrogen activity and rapidly progressing bone maturation.

\section{Discussion}

The results of this study showed that mild forms of central precocious puberty in girls can be identified at the first examination. They seem to be characterised by a combination of low plasma oestradiol and somatomedin $\mathrm{C}$, and normal or slightly advanced bone age at the time of diagnosis. We have shown that the course of the disease in these cases is also different from the usually severe forms of precocious puberty.

Bone maturation and height gain do not progress in parallel when sex hormones are secreted before puberty, and it is known that precocious puberty may accelerate epiphyseal fusion and lead to a reduction in final height. The fact that some patients in this group initially presented with normal or close to normal bone age provided an opportunity to assess the effect of moderate oestrogen activity on growth and to discuss the need for treatment with luteinising hormone releasing hormone analogue. The group of girls with mild precocious puberty seen nine months after the onset of clinical evidence of ovarian activity had only a moderate advance in bone age. The predicted final height remained normal. This indicates that height gain had been appropriate for bone age progression during this early period of the disease. This effect on skeletal growth was probably caused by low circulating oestradiol concentrations during the preceding year. It is comparable with the changes observed during the early period of normal puberty when growth acceleration accompanies or even precedes the appearance of sexual characteristics. ${ }^{17}$ Plasma somatomedin $\mathrm{C}$ values increase during normal puberty, and it has been suggested that this phenomenon in girls is mediated by the oestrogens indirectly through increased secretion of growth hormone rather than through a direct effect of oestradiol. ${ }^{18} 19$

In the present report, the plasma somatomedin $\mathrm{C}$ values were in the prepubertal range or slightly raised in girls with mild forms of precocious puberty, and pubertal in those with the severe form. A more complete evaluation of growth hormone secretion using spontaneous growth hormone profiles could not be performed in these patients, but in view of their plasma somatomedin $\mathrm{C}$ values it is possible that the growth hormone secretion in the mild form of precocious puberty did not increase to the extent seen in normal puberty during the Tanner P3 stage $^{20-22}$ or in patients with severe precocious puberty. ${ }^{18} 1923-25$ One might consider, therefore, that in addition to bone age the circulating value of plasma somatomedin $\mathrm{C}$ at the first examination reflected the ovarian activity, hence the severity of the disease. It is tempting to relate these data to recently reported results of skeletal response to low doses of oestrogens in girls with Turner's syndrome. ${ }^{26}{ }^{27}$ These authors reported a significant acceleration of growth without a concomitant change in plasma somatomedin $\mathrm{C}$. When low doses of ethinyloestradiol were used in these patients, growth rates increased without changes in bone maturation or plasma somatomedin C concentration. In the present study, a similar course of events occurred in the group of girls with less severe precocious puberty. In contrast, when pronounced oestrogen activity was present at first examination, its effect was predominant on bone maturation, leading to a reduced final height prediction. This was because the growth rate was not appropriate for bone age progression, in contrast to the group with moderate precocious puberty. 


\section{Precocious puberty in girls: early diagnosis of a slowly progressing variant 1175}

The spontaneous course of idiopathic precocious puberty in girls varies in presentation of symptoms and rate of progression: some cases show accelerated development while others may progress slowly or have totally regressive characteristics. ${ }^{1}$ The results of this study show that the lack of excessive progression of bone age and the plasma prepubertal somatomedin $\mathrm{C}$ values nine to 12 months after the onset of puberty are good indicators of moderate oestrogen activity. It is of interest that most of these cases of mild precocious puberty at time of diagnosis did not develop into severe and rapidly progressing precocious puberty. Furthermore, the age distribution did not differ between the groups. We suggest that girls with such moderate forms of precocious puberty be followed up for at least one year before deciding whether or not to have treatment with luteinising hormone releasing hormone analogue. Such treatment may be delayed as long as the final height prediction can be closely followed. Regression of pubertal signs may occur. If treatment is decided upon, it may be appropriate to re-evaluate the hypophyseal ovarian activity after two years of follow up to avoid unduly prolonged treatment. Probably all of these factors should be taken into consideration before committing a girl with central precocious puberty to treatment with the analogue.

In conclusion, an untreated group of girls with idiopathic central precocious puberty and moderate ovarian activity was followed for a period of two years. The data obtained at their first examination and in the course of their disease showed that bone maturation and plasma somatomedin $C$ values are helpful in identifying the less severe and potentially slowly progressing forms of central precocious puberty. These cases might not require immediate treatment with the luteinising hormone releasing hormone analogue and a close follow up may be preferred before treatment to evaluate their natural course.

We thank Mrs M Lacroix and C Chamot for secretarial assistance.

\section{References}

' Brauner R, Thibaud E, Rappaport R. Pubertés précoces centrales spontanément régressives chez la fille. Incidence sur les indications thérapeutiques dans les pubertés précoces. Ann Pediatr 1987;34:70-4.

2 Werder EA, Murset G, Zachmann M, Brook C, Prader A. Treatment of precocious puberty with cyproterone acetate. Pediatr Res 1974;8:248-56.

${ }^{3}$ Kaplan SA, Ling SM, Irani NG. Idiopathic isosexual precocity. Therapy with medroxyprogesterone. Am J Dis Child 1968;116: 591-8.

${ }^{4}$ Styne DM, Harris DA, Egli CA, et al. Treatment of true precocious puberty with a potent luteinizing hormone-releasing factor agonist: effect on growth, sexual maturation, pelvic sonography, and the hypothalamic-pituitary-gonadal axis. J Clin Endocrinol Metab 1985;61:142-51.

5 Pescovitz OH, Comite F, Hench K, et al. The NIH experience with precocious puberty: diagnostic subgroups and response to short-term luteinizing hormone releasing hormone analogue therapy. J Pediatr 1986;108:47-54.

${ }^{6}$ Beopple PA, Mansfield MJ, Wiermann ME, et al. Use of a potent, long acting agonist of gonadotropin-releasing hormone in the treatment of precocious puberty. Endocr Rev 1986;7: 24-33.

7 Brauner R, Rappaport R. Traitement des pubertés précoces centrales par un analogue du LHRH (HOE 766, Buserelin). Effet sur la croissance et la maturation osseuse après deux années de traitement. Arch Fr Pediatr 1987;44:271-6.

8 Brauner R, Thibaud E, Bishop P, Sizonenko PC, Rappaport R. Long term results of GnRH analogue (Buserelin) treatment in girls with central precocious puberty. Acta Paediatr Scand 1985; 74:945-9.

9 Tanner JM. Growth at adolescence. Oxford: Blackwell, 1978: 28-39.

10 Bayley N, Pinneau SR. Tables for predicting adult height from skeletal age: revised for use with Greulich Pyle hand standards. J Pediatr 1952;50:432-41.

11 Greulich WW, Pyle SI. Radiographic atlas of skeletal development of the hand and wrist. 2nd ed. Stanford: University Press, 1959.

12 Sempe M, Pedron G, Roy-Pernot MP. Auxologie, méthode et séquences. Paris: Theraplix, 1979.

13 Penny R, Blizzard RM, Davis MT. Sequential arginine and insulin tolerance test on the same day. J Clin Endocrinol Metab 1969;29:1499-501.

14 Furlanetto RW, Underwood LE, Van Wyk JJ, D'Ercole AJ. Estimation of Somatomedin-C levels in normals and patients with pituitary disease by radioimmunoassay. J Clin Invest 1977;60:648-57.

15 Rappaport R, Brauner R, Czernichow, P, et al. Effect of hypothalamic and pituitary irradiation on pubertal development in children with cranial tumors. J Clin Endocrinol Metab 1982; 54:1164-8.

16 Meisels A. Computed cytohormonal findings in 3307 healthy women. Acta Cytol 1965;9:328-33.

17 Tanner JM, Whitehouse RH, Hughes PC, Carter BS. Relative importance of growth hormone and sex steroids for the growth at puberty of trunk length, limbs length, and muscle width in growth hormone deficient children. $J$ Pediatr 1976;89:1000-8.

18 Harris DA, Van Vliet G, Egli CA, et al. Somatomedin-C in normal puberty and in true precocious puberty before and after treatment with a potent luteinizing hormone-releasing hormone agonist. J Clin Endocrinol Metab 1985;61:152-9.

19 Ross JL, Pescovitz OH, Barnes K, Loriaux DL, Cutler GB. Growth hormone secretory dynamics in children with precocious puberty. J Pediatr 1987;110:369-72.

20 Finkelstein JW, Roffwarg HP, Boyar RM, Kream J, Hellman L. Age related change in the twenty-four-hour spontaneous secretion of growth hormone. J Clin Endocrinol Metab 1972;35: 665-70.

21 Zadik Z, Chalew SA, Mc Carter RJ, Meistas M, Kowarski AA. The influence of age on the twenty-four-hour integrated concentration of growth hormone in normal individuals. J Clin Endocrinol Metab 1985;60:513-6.

22 Miller JD, Tannebaum GS, Colle E, Guyda HJ. Daytime pulsatile growth hormone seretion during childhood and adolescence. J Clin Endocrinol Metab 1982;55:989-94.

23 Pescovitz OH, Rosenfeld RG, Hintz RL, et al. Somatomedin-C in accelerated growth in children with precocious puberty. $J$ Pediatr 1985;107:20-5.

24 Rappaport R, Prevot C, Brauner R. Somatomedin C and growth in children with precocious puberty: A study of the effect of the level of GH secretion. J Clin Endocrinol Metab 1987;65: 1112-17. 
25 Mansfield MJ, Rudlin CR, Crigler JF, et al. Changes in growth and serum growth hormone and plasma somatomedin- $C$ levels during suppression of gonadal sex steroid secretion in girls with central precocious puberty. J Clin Endocrinol Metab 1988; 66:3-9.

26 Ross JL, Cassorla FG, Skerda M, Valk IM, Loriaux DL, Cutler GB. A preliminary study of the effect of estrogen dose on growth in Turner's syndrome. $N$ Engl J Med 1983;309:1104-6.

27 Ross JL, Long LM, Skerda M, et al. Effect of low doses of estradiol on 6 month growth rates and predicted height in patients with Turner syndrome. J Pediatr 1986;109:950-3.

Correspondence and requests for reprints to Dr $\mathbf{R}$ Brauner, Unité d'Endocrinologie Pédiatrique et Diabete, Hôpital des Enfants Malades, 149 Rue de Sévres, 75015, Paris, France.

Accepted 13 February 1989 